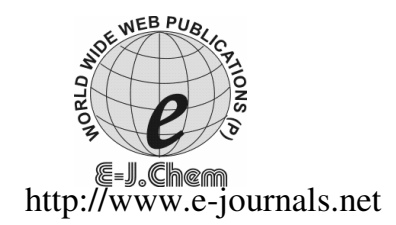

ISSN: 0973-4945; CODEN ECJHAO

E-Journal of Chemistry 2011, 8(2), 938-944

\title{
Study on the Significance of Temporal Ion Chemistry in Groundwater of Dindigul District, Tamilnadu, India
}

\author{
R. MANIVANNAN, S. CHIDAMBARAM*, P. ANANDHAN, U. KARMEGAM, \\ C. SINAGARAJA, G. JOHNSONBABU and M. V. PRASANNA ${ }^{\S}$
}

\author{
Department of Earth Sciences \\ Annamalai University, Annamalai Nagar, Tamilnadu, India \\ ${ }^{\S}$ School of Engineering and Science \\ Department of Applied Geology \\ Curtin University of Technology, Sarawak, Malaysia \\ chidambaram_s@rediffmail.com
}

Receivd 10 April 2010; Accepted 25 June 2010

\begin{abstract}
The demand of water supply is increasing day by day to meet the pace of developments in domestic, agricultural and industrial sectors especially in developing countries like India. Groundwater being a scarce commodity in a hard rock terrain like Dindigul district an attempt has been made in this study brings out the significance of temporal ion chemistry in groundwater by collecting groundwater from 43 different location of the district and analysed for major and minor ions. These ions were then used for the irrigation classification of groundwater and to bring out the mechanisms responsible of the water chemistry of the region during different seasons.
\end{abstract}

Keywords: Water chemistry, Groundwater, Ion evolution, Temporal ion.

\section{Introduction}

Groundwater is the main source for drinking, domestic, industrial and agricultural purposes. Vagaries of monsoon and withdrawal of groundwater in excess to replenishment of aquifer system in many parts of India result into continuous declining of water table, causing reduction in water supply and deterioration of its quality. A detailed study in the groundwater quality in the hard rock aquifers in and around Dindigul town was carried out by Mondal and Singh ${ }^{1,2}$. The study area is known for its leather industries ${ }^{3}$ at present more than 80 units are well established. Processing of leather requires a large amount of freshwater along with various chemicals. Every $10 \mathrm{~kg}$ of raw skin tanned requires about $350 \mathrm{~L}$ of freshwater. During the past 
few decades, the groundwater is being contaminated and it's giving rise to health problems and epidemics. A study on the geochemical variation in the groundwater of the entire district was lacking, though it had report of fluoride ${ }^{4}$ and that of tannery pollution. This paper aims to bring out the variation of ions in different season and its application to find out the utility along with the dominant geochemically significant process active in the study area during different seasons.

\section{Experimental}

\section{Study area}

The Dindigul district is a hard rock terrain located in south part of Tamilnadu, India. It lies in between $9^{\circ} 91^{\prime}$ and $10^{\circ} 84^{\prime}$ North latitudes and $77^{\circ} 24^{\prime}$ and $78^{\circ} 44^{\prime}$ East longitudes (Figure 1) covering a total area of 6,26 6.64 Sq. km. The normal annual rainfall over the district varies from about $700 \mathrm{~mm}$. to about $1600 \mathrm{~mm}$. The study area enjoys a tropical climate. The periods from April to June are generally hot and dry (Summer) and it is pleasant during November to January (Winter). The relative humidity varies between 65 and $85 \%$. Water is stored in weathered charnockite and granite gneisses. The depth to water level ranges from $0.12 \mathrm{~m} \mathrm{bgl}$ to $15 \mathrm{~m} \mathrm{bgl}^{4} \mathrm{~A}$ total of 172 groundwater samples were collected in four different seasons during the period from 2008 to 2010 covers pre-monsoon (PRM) during May, South West Monsoon (SWM) during August, North East Monsoon (NEM) during November and Post Monsoon (POM) during February. The samples were analysed for different ions like $\mathrm{HCO}_{3}, \mathrm{Cl}, \mathrm{SO}_{4}, \mathrm{PO}_{4}, \mathrm{NO}_{3}, \mathrm{~F}$, $\mathrm{H}_{4} \mathrm{SiO}_{4}, \mathrm{Ca}, \mathrm{Mg}, \mathrm{Na}, \mathrm{K}$ and parameters like EC, $\mathrm{pH}$ and TDS using standard procedures ${ }^{5-7}$ to understand the geochemical behaviour.

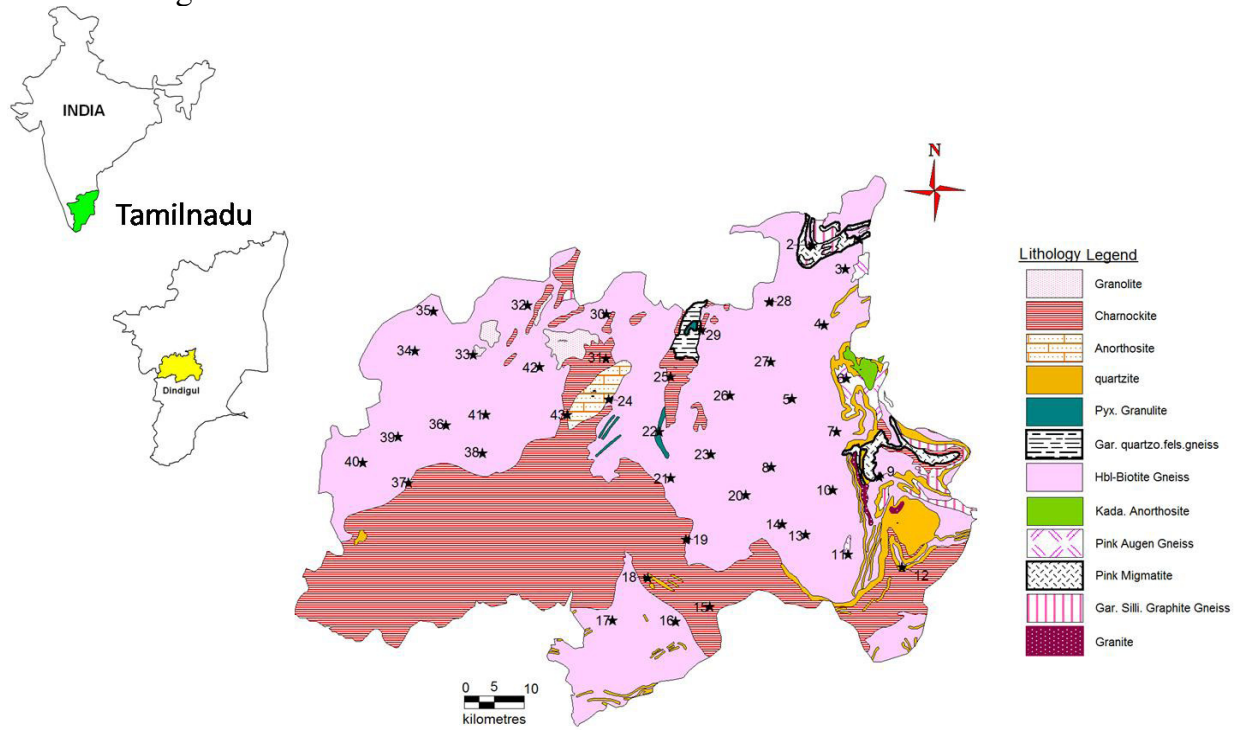

Figure 1. Geological map showing the sampling locations

\section{Results and Discussion}

The maximum, minimum and average of the analytical results for different seasons are represented in Table 1. In general the ion dominance shows that $\mathrm{HCO}_{3}>\mathrm{Cl}>\mathrm{SO}_{4}>\mathrm{NO}_{3}$ trend of anions and that of cations is $\mathrm{Na}>\mathrm{Ca}>\mathrm{Mg}>\mathrm{K}$.

\section{Salinity hazard}

Excess salt increases the osmotic pressure of the soil solution that can result in a physiological drought condition. Even though the field appears to have plenty of moisture, the plants wilt because insufficient water is absorbed by the roots to replace those lost by transpiration. 
Table 1. Summary of water chemistry (all values in ppm except EC in $\mu \mathrm{s} / \mathrm{cm}$ and $\mathrm{pH}$ ) salinity hazard

\begin{tabular}{cccccccccccc}
\hline Season & $\mathrm{pH}$ & $\mathrm{EC}$ & $\mathrm{Ca}$ & $\mathrm{Mg}$ & $\mathrm{Na}$ & $\mathrm{K}$ & $\mathrm{Cl}$ & $\mathrm{HCO}_{3}$ & $\mathrm{SO}_{4}$ & $\mathrm{H}_{4} \mathrm{SiO}_{4}$ \\
\hline \multirow{4}{*}{ PRM } & Max & 8.90 & 3272.00 & 148.00 & 158.40 & 555.10 & 221.00 & 833.00 & 500.00 & 194.00 & 5.20 \\
& Min 7.80 & 620.00 & 12.00 & 24.00 & 54.70 & 13.00 & 56.00 & 122.00 & 8.00 & 0.40 \\
& $\mathrm{Avg}$ & 8.36 & 1717.71 & 48.49 & 67.81 & 236.07 & 57.53 & 327.73 & 290.27 & 64.53 & 2.79 \\
& $\mathrm{M}$ & 8.50 & 5800.00 & 124.00 & 122.00 & 647.00 & 268.10 & 974.00 & 671.00 & 168.00 & 71.00 \\
$\mathrm{SWM}$ & Min 6.20 & 632.00 & 12.00 & 5.00 & 26.00 & 2.30 & 36.00 & 98.00 & 4.00 & 2.00 \\
& Avg & 7.23 & 2240.53 & 51.29 & 49.89 & 243.76 & 27.14 & 316.60 & 427.89 & 32.64 & 25.15 \\
& Max & 8.97 & 5140.00 & 152.00 & 98.00 & 563.00 & 161.00 & 903.00 & 524.00 & 106.00 & 9.90 \\
NEM & Min 7.10 & 465.00 & 20.00 & 5.00 & 30.00 & 0.65 & 54.00 & 229.00 & 12.50 & 1.50 \\
& Avg 8.41 & 2064.29 & 62.69 & 40.24 & 241.51 & 20.22 & 340.60 & 377.20 & 44.38 & 6.65 \\
& Max 8.67 & 2675.00 & 126.00 & 103.20 & 398.00 & 94.00 & 584.90 & 732.00 & 156.00 & 42.00 \\
POM & Min 6.86 & 546.00 & 20.00 & 14.40 & 20.30 & 2.80 & 53.17 & 170.80 & 10.00 & 0.79 \\
& Avg 7.41 & 1519.42 & 63.64 & 66.23 & 144.92 & 24.83 & 249.95 & 401.08 & 48.07 & 25.75 \\
\hline
\end{tabular}

The Wilcox diagram (Figure 2) shows that during the post monsoon most of the samples fall in C3 category (High salinity hazard) and the majority of samples collected from NEM, PRM and SWM falls range from C2-C4 (Medium to very high salinity hazard, Figure 2) of which the SWM and NEM shows good representation of very high salinity hazards.

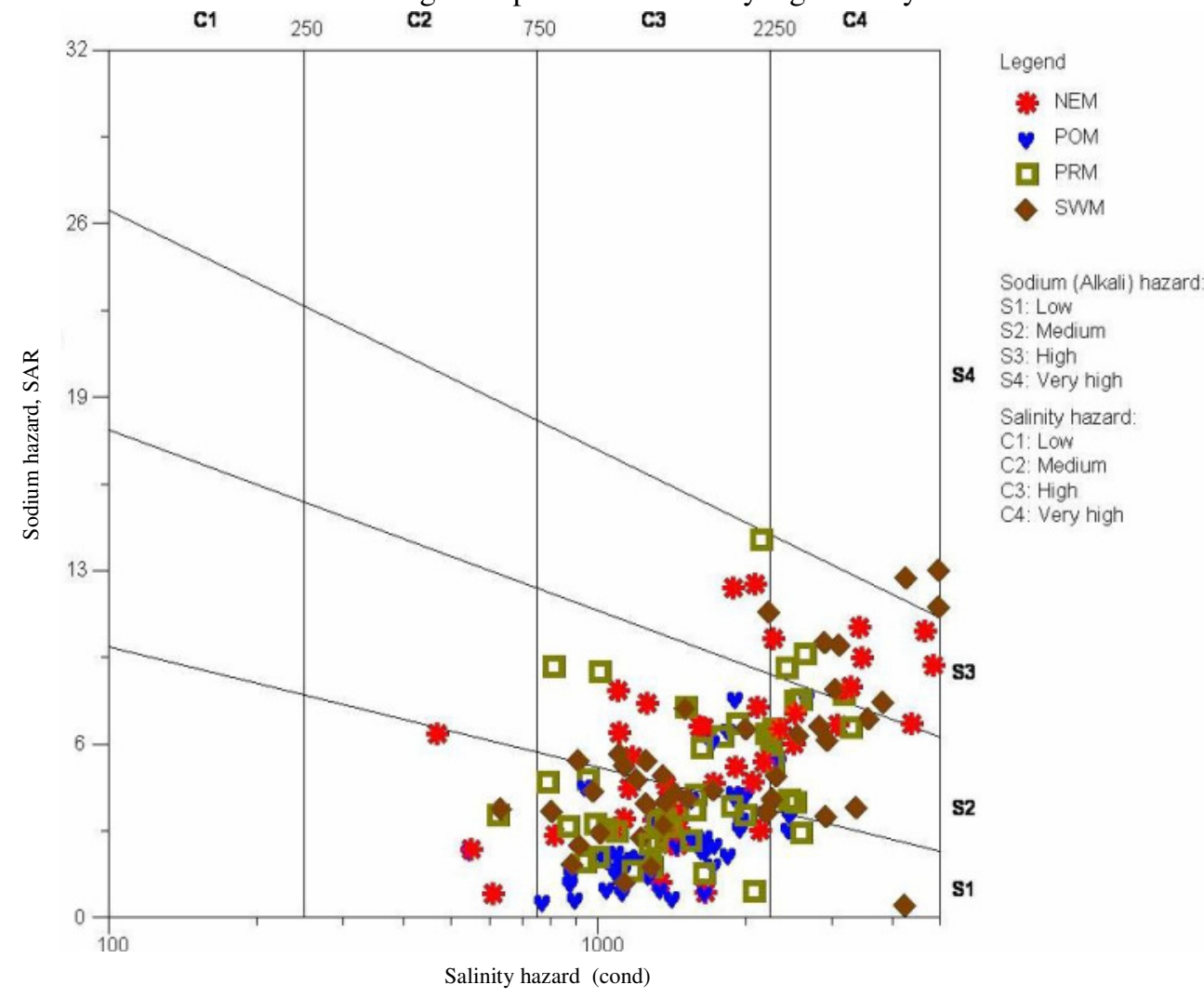

Figure 2. Wilcox classification of ground water for irrigation purpose (SAR: Sodium Adsorption Ratio) 


\section{Sodicity hazard}

Salinity, sodicity and toxicity generally need to be considered for evaluation of the suitable quality of groundwater for irrigation ${ }^{8}$. The sodicity hazard was determined by absolute and relative cation concentrations. If the content of sodium is high, the sodicity hazard is high and vice versa. If calcium and magnesium are dominant, the hazard is low. The classification of irrigation water with respect to SAR (Sodium Adsorption Ratio) is mainly based on the effect of exchangeable sodium on the physical condition of the soil.

$$
S A R=\frac{N a}{\frac{\sqrt{C a+M g}}{2}}
$$

The values of sodium adsorption ratio and groundwater electrical conductivity are the main criteria that characterise the degree of soil salinization and alkalization hazards in the processes of fluctuation of the shallow mineralised groundwater, or in flow regime processes if such groundwater is used for irrigation. The unfit waters due to high electrical conductivity will cause salinization ${ }^{9,10}$. The unfit water samples (containing excess of carbonate and bicarbonate) for irrigation will precipitate soil solution calcium and increase solution sodium, resulting in soil dispersion ${ }^{11}$ as well as impaired nutrient uptake by plants. Most of the samples of POM fall in the low sodium hazards region that of PRM, NEM and SWM are distributed from S1 to S2 category (Low to High, Figure 2). The monsoon samples have good representation in S2 and S3 category of among which the SWM also shows representation in $\mathrm{S} 4$ category (Very high sodium hazards).

In general, the increase of ions concentration results in the unsuitability of water for irrigation purpose with higher electrical conductivity and sodium hazards during monsoon. The majority of samples of these seasons fall in C2S1, C3S1, C3S2, C4S2, C4S3 and C4S4. The cluster of PRM fall in C3S1 and C3S2 category this may be due to dissolution of minerals, dispersive of ions, agricultural practices etc., during: POM season the quality is comparably better to the other seasons with samples groping in C3S1 category. Applications of gypsum in these soil increases soil permeability ${ }^{12}$. In addition to SAR and $\mathrm{Na} \%$, the excess carbonate and bicarbonate in groundwater over the sum of calcium and magnesium also influences the unsuitability of groundwater for irrigation. This is defined as Residual Sodium Carbonate (R.S.C) ${ }^{13}$.

\section{Piperfacies}

Piper $^{14}$ classified hydrogeochemical facies using tri-linear diagram. It consists of two lower triangular fields and a central diamond shaped field. All the three fields have incorporation of major ions only. The Triangular fields are plotted separately with epm values of cations $\left(\mathrm{Ca}^{2+}, \mathrm{Mg}^{2+}\right)$ alkali earth, $\left(\mathrm{Na}^{++} \mathrm{K}^{+}\right)$alkali, $\left(\mathrm{HCO}_{3}^{-}\right)$weak acid and $\left(\mathrm{SO}_{4}{ }^{2-}\right.$ and $\left.\mathrm{Cl}-\right)$ strong acid. Water facies can be identified by projection of plots in the central diamond shaped field. This plot has been applied by several authors to understand the hydrogeochemical facies ${ }^{7}$. Hydrogeochemical facies interpretation is a useful tool for determining the flow pattern, origin of chemical histories of groundwater. The piper diagram used for comparing quality of water.

The evolution of ground water chemistry represented by the samples falling in Figure 3 shows that most of the PRM samples are $\mathrm{Na} C$ lype showing the dominance of sodium and chloride there are untreated effluent of tanneries distributed in this district also have the dominance of $\mathrm{Na}$ and $\mathrm{Cl}$ ions. 


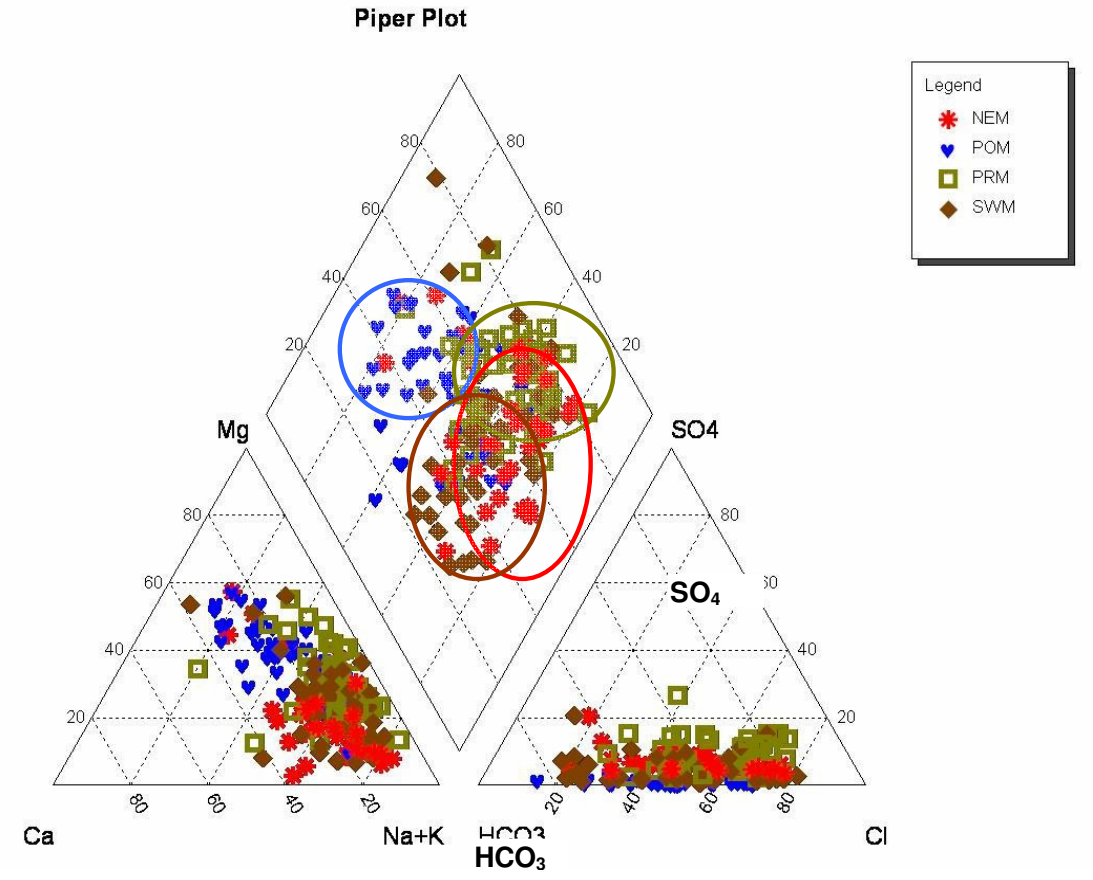

Figure 3. Piper tri-linear diagram for hydrogeochemical facies

During the SWM they are represented in $\mathrm{Na} \mathrm{HCO}_{3}$ type and followed by NEM combination of $\mathrm{NaCl}$ and $\mathrm{Na} \mathrm{HCO}_{3}$ type. The POM shows dominance of $\mathrm{CaHCO}_{3}$ type. The study area being hard rock terrain during PRM higher concentration of mono-valant anions and cations are noted. Later SWM results in dissolution of minerals and introduces the dissolved carbonates and makes the water type $\mathrm{NaHCO}_{3}$. Later during the NEM a combination of lesser influence of rainfall and anthropogenic activities (Agriculture, tanneries) is noted. Results in a combination water type as $\mathrm{NaCl}$ and $\mathrm{NaHCO}_{3}$. During PRM due to the ion exchange process by the replacement of $\mathrm{Na} / \mathrm{Ca}$ results in $\mathrm{Ca}^{\mathrm{HCO}_{3}}$ type. The geochemical nature of ground water in the study area during different seasons represented as follow $\mathrm{NaCl}-\mathrm{NaHCO}_{3}-\mathrm{NaCl}, \mathrm{NaHCO}_{3}$

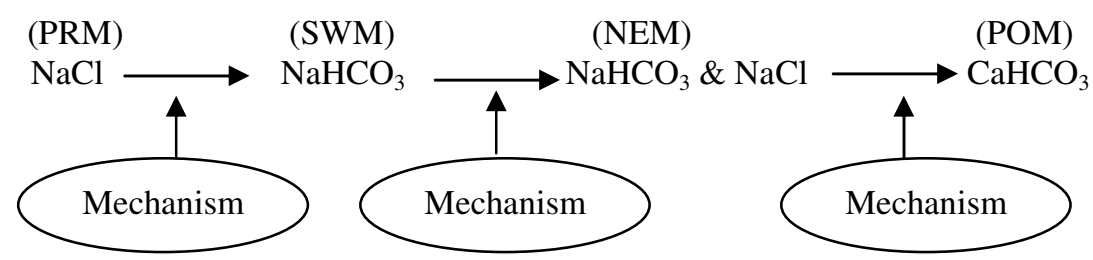

\section{Mechanism 1}

Dissolution and weathering of minerals results in higher concentration of bicarbonate ions.

$$
\begin{aligned}
& \mathrm{Na}_{0.78} \mathrm{CaO}_{0.22} \mathrm{Al}_{1.22} \mathrm{Si}_{2.78} \mathrm{O}_{8}+3.73 \mathrm{H}_{2} \mathrm{O}+1.22 \mathrm{H}_{2} \mathrm{CO}_{3} \longrightarrow 0.61 \mathrm{Al}_{2} \mathrm{Si}_{5}(\mathrm{OH})_{4} 1.56 \mathrm{H}_{4} \mathrm{SiO}_{4}+ \\
& 0.78 \mathrm{Na}+0.22 \mathrm{Ca}^{2+}+1.22 \mathrm{HCO}_{3}^{-} \text {. } \\
& \mathrm{Na}_{0.6} \mathrm{Ca}_{0.4} \mathrm{Al}_{1.4} \mathrm{Si}_{2.6} \mathrm{O}_{8}+2.69 \mathrm{H}_{2} \mathrm{O}+1.25 \mathrm{CO}_{2} \longrightarrow 0.18 \mathrm{Al}_{2} \mathrm{Si}_{2} \mathrm{O}_{5}(\mathrm{OH})_{4}+22 \mathrm{Ca}_{0.33} \\
& \mathrm{Al}_{4.67} \mathrm{Si}_{7.33} \mathrm{O}_{20}(\mathrm{OH})_{4}+0.6 \mathrm{Na}^{+}+0.32 \mathrm{Ca}^{2+}+1.25 \mathrm{HCO}_{3}^{-}+0.63 \mathrm{H}_{4} \mathrm{SiO}_{4} \\
& 3 \mathrm{~K}_{2}(\mathrm{MgFe})_{3} \mathrm{Al}_{2} \mathrm{Si}_{6} \mathrm{O}_{20}(\mathrm{OH})_{4}+24 \mathrm{H}_{2} \mathrm{O}+18 \mathrm{H}_{2} \mathrm{CO}_{3} \longrightarrow \\
& 2\left(\mathrm{Mg}_{3} \mathrm{Fe}_{3}\right) \mathrm{Al} 3 \mathrm{Si}_{50} \mathrm{O}(\mathrm{OH}) 4.8 \mathrm{H}_{2} \mathrm{O}+6 \mathrm{~K}+3 \mathrm{Mg}^{2+}+8 \mathrm{H}_{4} \mathrm{SiO}_{4}+18 \mathrm{HCO}_{3}^{-}
\end{aligned}
$$


Dissolution of all minerals results in the increase of bicarbonate concentration in groundwater ${ }^{15}$. Minerals such as plagioclase feldspar and biotite mica are represented in the above equation.

\section{Mechanism 2}

The association of $\mathrm{Na}$ and $\mathrm{Cl}$ during the pre-monsoon reflects the various chemicals are used in tanning include common salt, sodium sulphate, chrome sulphate, fat liquors, vegetable oils and dyes $^{1,16}$. Wastewater discharged for $100 \mathrm{~kg}$ of skin and hide processed varies from 3000 to $3200 \mathrm{~L}$. The biggest polluting material in the tanning industry, which is difficult to get rid off is common salt. For every 10 tons of salted hide and skin processed, 2-3 tons of salt is removed and in addition another one ton of salt is removed while pickling ${ }^{16}$. Tannery waste is characterized by its strong colour (reddish to dull brown), high BOD, $\mathrm{pH}$ and high dissolved solids. Na along with $\mathrm{HCO}_{3}$ and $\mathrm{Cl}$ can be interpreted as a soluble salts component. Since this occurs during NEM both the process of mineral dissolution and pollution are dominant in the study area.

\section{Mechanism 3}

The processes of ion exchange results in the $\mathrm{Ca} \mathrm{HCO}_{3}$ water type. There are substances which absorb and exchange their cations, with cations present in the groundwater. The exchange process of $\mathrm{Na}$ in water for $\mathrm{Ca}$ and $\mathrm{Mg}$ in soil reduces the permeability and eventually results in soil with poor internal drainage. Hence, air and water circulation is restricted during wet conditions and such soils are usually hard when dry ${ }^{17}$. Variation of anions from recharge to discharge varies from $\mathrm{HCO}_{3} \rightarrow \mathrm{Cl}$ type due to the dissolution of ions in the pathway or due to precipitation and removal of $\mathrm{HCO}_{3}$ from the aqueous system ${ }^{18}$. Hydrogeochemical pattern correlates with the flow pattern of ground water in the basin ${ }^{13}$. Low TDS, high Ca: Mg ratio, low $\mathrm{SO}_{4}$ and high $\mathrm{HCO}_{3}$ occurs in the recharge area and the reverse in the discharge area.

\section{Conclusion}

The chemical parameters in groundwater help us to understand the utility and the geochemical evolutionary path ways in different seasons. The irrigation classification of groundwater shows that the water has to be used in caution that too in regions with good drainage. The post monsoon has good quality of irrigation water when compared to other seasons. The piper diagram depicts that there are three basic mechanisms operating in different seasons in the study area such as anthropogenic activities, weathering and dissolution of minerals and ion exchange. Thus the study on the chemical variation of ions in different seasons reveals that the utility of water varies with different season and different geochemical process interplay and determine the groundwater chemistry of the study area.

\section{Acknowledgment}

Authors would like to thank the DST- Fast track scheme for help extended by financial support

\section{References}

1. Mondal N C and Singh V S, In Proceeding of the 2nd Asia Pacific Association of Hydrology and Water Resources Conference, 5-9 July 2004, Suntec, Singapore, Vol. II, 436-444.

2. Mondal N C, Singh V S, Sarma M R K and Thangarajan M, Impact of tannery effluent in groundwater And its control: A case study in and around Dindigul, Tamil Nadu, India. In: Proceedings of ICHWM-2002, BS Publisher; 2002. Vol. II, 596-604 
3. Paul Basker J, Peace Trust, 2000, 208-210.

4. CGWB (Central Groundwater Board) Annual Report, South Eastern Coastal Region, 2008.

5. APHA Standard methods for the examination of water and wastewater (American Public Health Association), Washington DC, 1995.

6. Ramesh R and Anbu M, Chemical Methods for Environmental Analysis-Water and Sediments, 1996, 161.

7. Chidambaram S, Hydrogeochemical Studies of Groundwater in Periyar District, Tamilnadu, India, Ph.D Thesis, Department of Geology, Annamalai University, India, 2000.

8. Todd D K, Groundwater Hydrology, Wiley, New York, 1980.

9. Ghafoor A F, Ullah and Abdullah M, Pakistan J Agri Sci., 1990, 27, 294-298.

10. Goyal R S and Jain B L, J Indian Soc Soil Sci., 1982, 30(4), 447-454.

11. Emerson W W and Bakker A C, Australian J Soil Res., 1973, 11, 151-152.

12. Ghafoor A, Azam M and Shoaib M, Pakistan J Soil Sci., 1993, 8, 1-2.

13. Opnanari DU and Toth S, Groundwater, 1989, 27(1), 20-26.

14. Piper A M Trans Am Geophysical Union, 1944, 25, 914-923.

15. Drever I J, The Geochemistry of Natural Waters, $2^{\text {nd }}$ Edition, Englewood Cliffs NJ (Eds) Prentice Hall, 1988, 388.

16. Mondal N C and Singh V S, Curr Sci., 2004, 87, 658-662.

17. Wilcox L V, The Quality Water for Irrigation Use, US Dept Agric Bull., 1955.

18. Tirumalesh K, Shivanna and Jalihal A A, Hydrogeol J., 2007, 15(3), 589-598. 


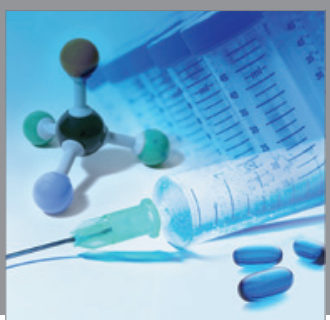

International Journal of

Medicinal Chemistry

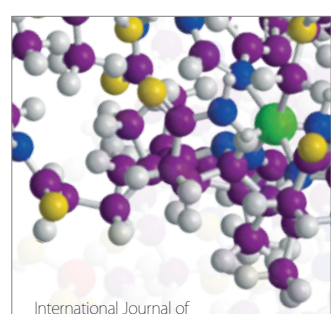

Carbohydrate Chemistry

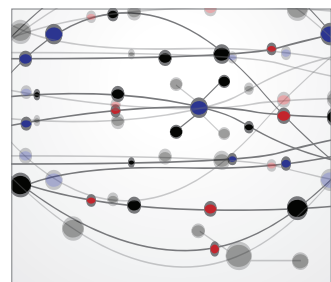

The Scientific World Journal
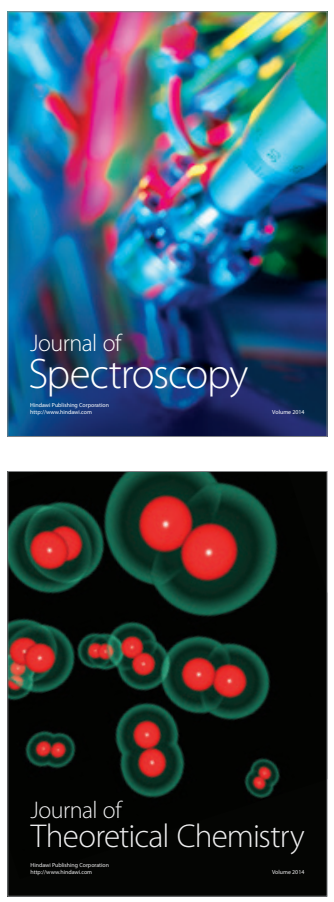
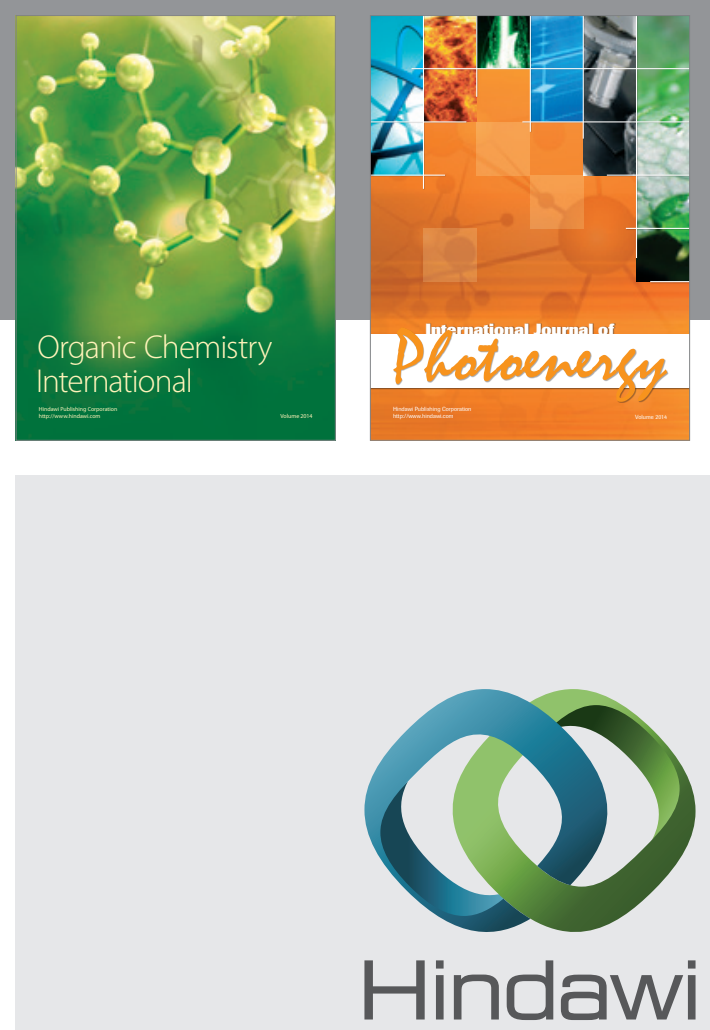

Submit your manuscripts at

http://www.hindawi.com
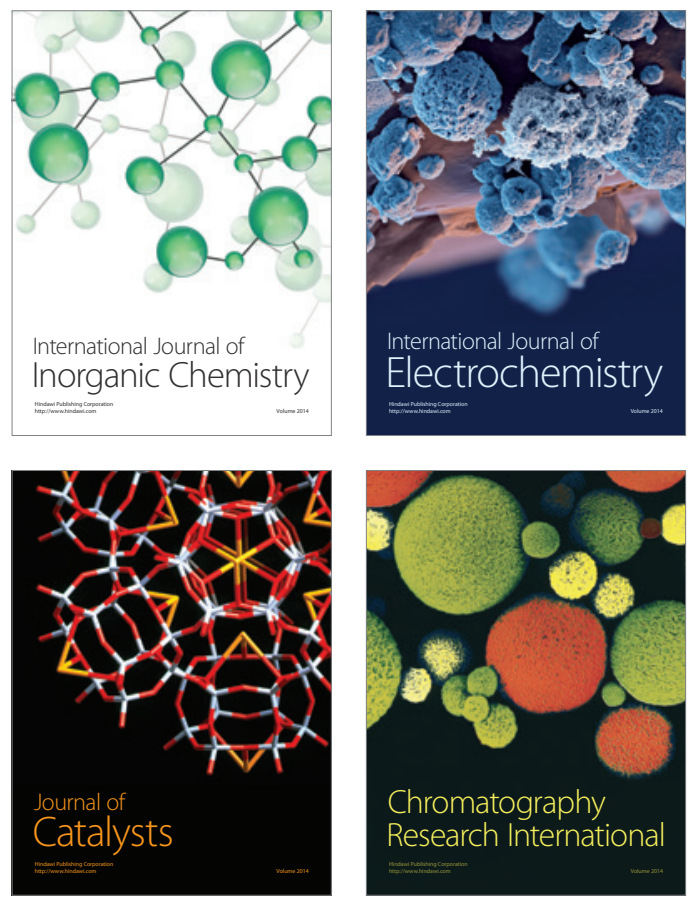
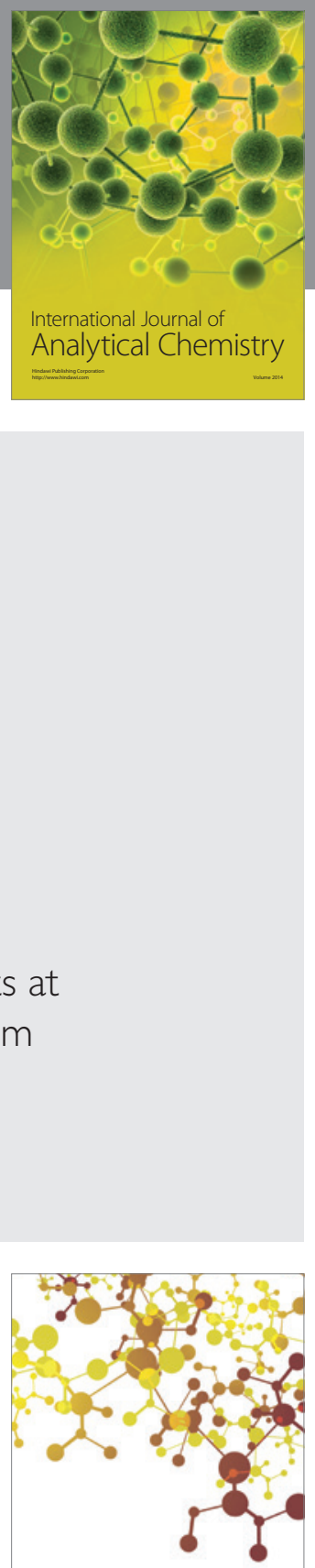

Journal of

Applied Chemistry
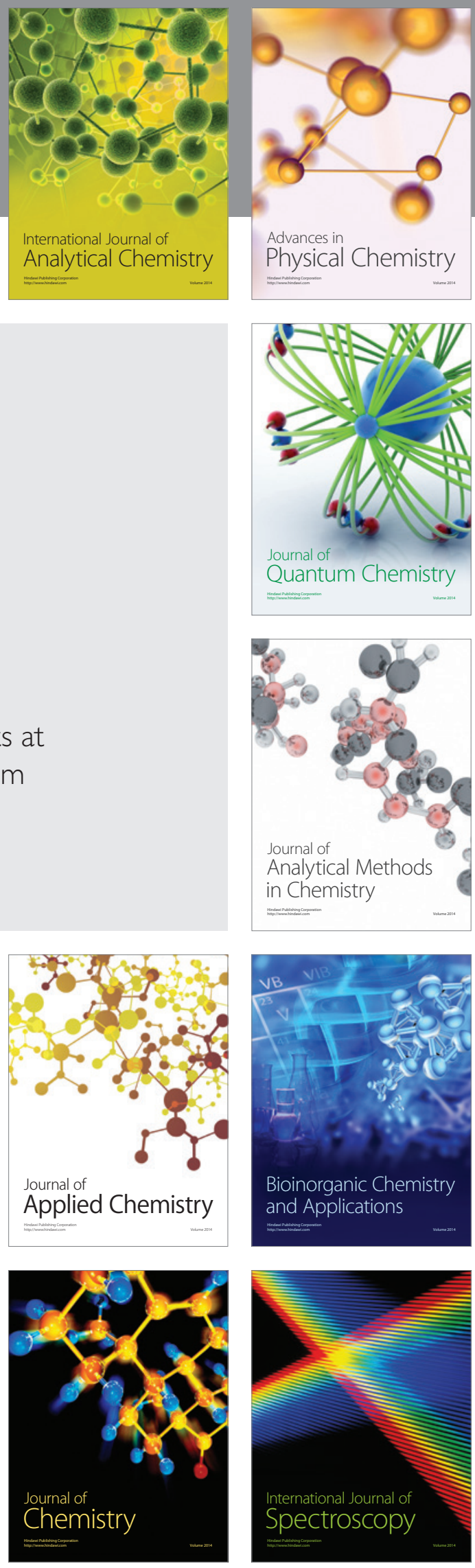